\title{
Electrode Potentials of a Silver-Silver Chloride Electrode vs. Temperature for Biosensors
}

\author{
Isao Dendo Member ( Tohoku Institute of Technology, dendo@tohtech.ac.jp ) \\ Kana Seki Non-member ( Tohoku Institute of Technology, k-seki@tohtech.ac.jp )
}

\begin{abstract}
Keywords : silver-silver chloride electrode, electrochemical sensor, biosensor, isothermal coefficient, non-isothermal coefficient, thermal
\end{abstract} coefficient

The temperature coefficients of the electrode potential of a silver-silver chloride electrode vs. silver-silver chloride electrode are experimentally examined in potassium chloride or sodium chloride solutions. The aim of these experiments is to make clear the effect of temperature on the potentials of silver-silver chloride electrodes in those solutions for micro biosensor applications.

The silver-silver chloride electrode is electrolytically processed in potassium chloride or sodium chloride solutions of $1[\mathrm{~mol} / \mathrm{kg}]$ at room temperature. The length and diameter of the electrode are $20[\mathrm{~mm}]$ and $3[\mathrm{~mm}]$, respectively. The deposited amount of silver chloride on the electrode surface is apparently $3\left[\mathrm{C} / \mathrm{cm}^{2}\right]$ at the current density of $1\left[\mathrm{~mA} / \mathrm{cm}^{2}\right]$.

The electrode potential derived from the Nernst equation is given by the ionic activity of chloride and the temperature. Non-isothermal coefficients, or thermal coefficients of silver-silver chloride electrode potentials in the concentrations of 0.1 to $1[\mathrm{~mol} / \mathrm{kg}]$ are measured in the range of 15 to $45\left[{ }^{\circ} \mathrm{C}\right]$. The non-isothermal state is the state of the different temperature of solutions of a sample electrode and the reference. The non-isothermal potentials vs. temperature characteristics in $0.1 \sim 1[\mathrm{~mol} / \mathrm{kg}]$ of potassium chloride are shown in Fig. 1. The coefficients in potassium chloride and sodium chloride solutions vs. the ionic activities are shown in Fig. 2 . They are $0.42\left[\mathrm{mV} /{ }^{\circ} \mathrm{C}\right]$ at $0.1[\mathrm{~mol} / \mathrm{kg}]$ and $0.26\left[\mathrm{mV} /{ }^{\circ} \mathrm{C}\right]$ at $1[\mathrm{~mol} / \mathrm{kg}]$ in potassium chloride, and almost the same in sodium chloride solutions.

Isothermal coefficients are also measured. The isothermal state is the state of both of a sample electrode and the reference are in the same temperature solution. Although the isothermal

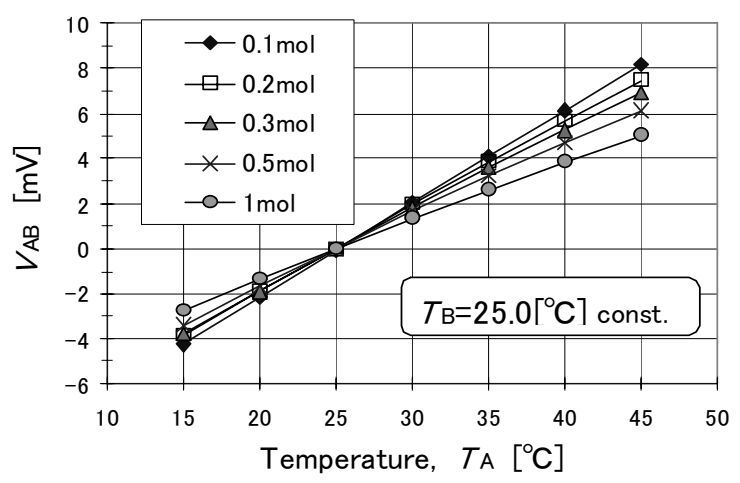

Fig. 1. Non-isothermal $\mathrm{Ag}-\mathrm{AgCl}$ Electrode Potentials $V_{\mathrm{AB}}$ Vs. Temperature in $\mathrm{KCl}$ Solutions coefficient must theoretically be zero by definition for all temperatures, the differnce of potentials between a pair of electrodes, which is called as offset voltage, appears practically, because of the ununiformity of the electrode surfaces. An example of behavior of isothermal potentials is shown in Fig. 3. The isothermal coefficients in potassium chloride are $3 \sim 4\left[\mu \mathrm{V} /{ }^{\circ} \mathrm{C}\right]$ in $0.1[\mathrm{~mol} / \mathrm{kg}]$ and $0.3\left[\mu \mathrm{V} /{ }^{\circ} \mathrm{C}\right]$ in $1[\mathrm{~mol} / \mathrm{kg}]$ at the steady state of the temperature. They are less than $1 / 100$ times of their non-isothermal coefficients. The values are depending on the degree of the uniformity of electrode surface. There is no differnce on the behavior in potassium and sodium chloride solutions.

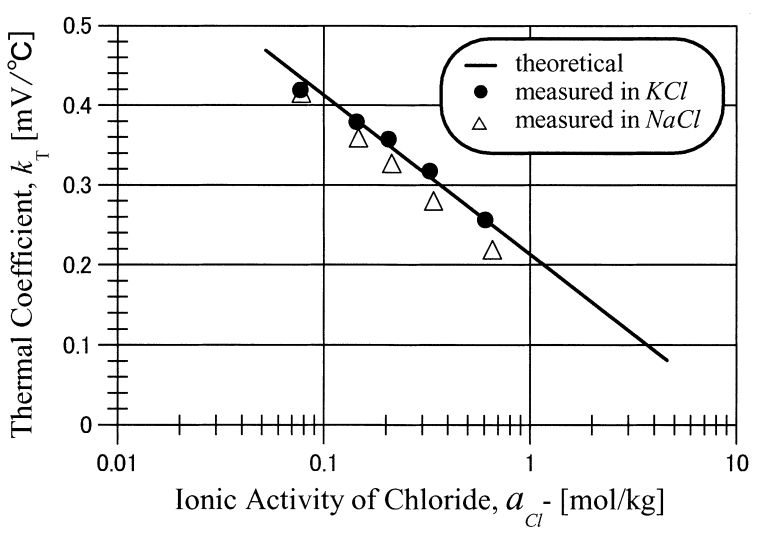

Fig. 2. Non-isothermal Coefficient of $\mathrm{Ag}-\mathrm{AgCl}$ Electrode Potentials vs. Ionic Activity of Chloride in $\mathrm{KCl}$ Solutions

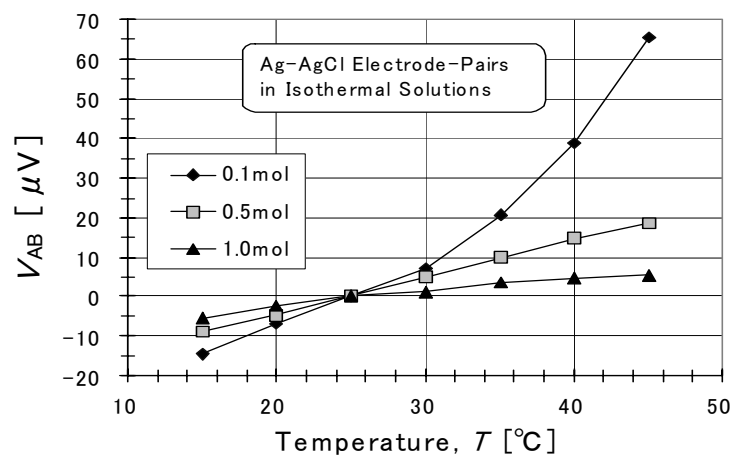

Fig. 3. Isothermal $\mathrm{Ag}-\mathrm{AgCl}$ Electrode Potentials $V_{\mathrm{AB}}$ vs. Temperature in $\mathrm{KCl}$ Solutions 


\title{
バイオセンサ用銀-塩化銀電極の電極電位一温度特性 \\ 正員 田頭 功* 非会員 関 加奈*

\author{
Electrode Potentials of a Silver-Silver Chloride Electrode vs. Temperature for Biosensors \\ Isao Dendo*, Member, Kana Seki*, Non-member
}

\begin{abstract}
The aim of this study is to make clear the effect of temperature on the potentials of silver-silver chloride $(A g-A g C l)$ electrodes in potassium chloride $(\mathrm{KCl})$ and sodium chloride $(\mathrm{NaCl})$ solutions for micro biosensor applications. Non-isothermal coefficients, or thermal coefficient of $\mathrm{Ag}$ - $\mathrm{AgCl}$ electrodes in the concentrations of 0.1 to $1.0[\mathrm{~mol} / \mathrm{kg}]$ were experimentally measured in the range of 15 to $45\left[{ }^{\circ} \mathrm{C}\right]$. The electrode was prepared by electrolytical process in $\mathrm{KCl}$ or $\mathrm{NaCl}$ solutions. The length and diameter of the electrode are $20[\mathrm{~mm}]$ and $3[\mathrm{~mm}]$, respectively. The coefficients in $K C l$ solutions were $0.42\left[\mathrm{mV} /{ }^{\circ} \mathrm{C}\right]$ in $0.1[\mathrm{~mol} / \mathrm{kg}]$ and $0.26\left[\mathrm{mV} /{ }^{\circ} \mathrm{C}\right]$ in $1.0[\mathrm{~mol} / \mathrm{kg}]$ and almost the same in $\mathrm{NaCl}$ solutions. Isothermal coefficients were also measured. Although the coefficients must theoretically be zero by definition for all temperatures, the difference of potentials between a pair of electrodes which is called as offset voltage appears practically. They were $3 \sim 4\left[\mu \mathrm{V} /{ }^{\circ} \mathrm{C}\right]$ in $0.1[\mathrm{~mol} / \mathrm{kg}]$ and $0.3\left[\mu \mathrm{V} /{ }^{\circ} \mathrm{C}\right]$ in $1[\mathrm{~mol} / \mathrm{kg}]$ at the steady state of temperature. The values were depending on the degree of the uniformity of electrode surface.
\end{abstract}

キーワード : 銀-塩化銀電極, 電気化学センサ, バイオセンサ, 等温温度係数, 非等温温度係数, 熱温度係数

Keywords : silver-silver chloride electrode, electrochemical sensor, biosensor, isothermal coefficient, non-isothermal coefficient, thermal coefficient

\section{1. まえがき}

生体内の電気的信号の導出や電気化学的原理を利用した 生体用センサには，銀-塩化銀電極がよく用いられる。生体 計測において重要な電極として, 銀-塩化銀電極の特性に関 する多くの研究報告(1)〜(3)などがある。しかし，具体的な 生体計測においては，いろいろな課題に直面することが多 w。

本研究では, その課題の 1 つである電気化学的原理を利 用したマイクロバイオセンサなどを念頭に, 電極電位の温 度の影響に関する実験的な検討を行ったので報告する。

ここではセンサが計測対象とする量が電圧信号である場 合を想定し, 1 対の銀-塩化銀電極間の電位差, すなわち電 極間オフセット電圧の温度特性について調べた。温度状態 としては，実際にセンサ使用時に考えられるつぎの 2 つの 場合を選んだ。1つは，1 対の電極間の溶液温度が過渡的に 異なった值になる非等温（non-isothermal）状態であり，も う 1 つは, 2 つの電極は共に等しい温度に置かれながら温度 が変化する等温（isothermal）状態である。なお，この実験 では電解溶液として最も代表的な塩化カリウム溶液を使用

\footnotetext{
* 東北工業大学工学部環境情報工学科

干982-8577 仙台市太白区八木山香澄町 35-1

Dept. of Environmental Information Engineering, Tohoku Institute of Technology

35-1 Kasumicyo Yagiyama, Taihaku-ku, Sendai 982-8577
}

したが，比較のために塩化ナトリウム溶液についても実験 を行った。

非等温状態における単位温度変化による電極間オフセッ 卜電圧の変化量, すなわち非等温温度係数 (non-isothermal coefficient）はネルンストの式から理論的に求められる。そ の温度係数は塩化物イオン濃度により異なるが, 溶液濃度 $0.1 \sim 1.0[\mathrm{~mol} / \mathrm{kg}]$ において実測された值は理論值によく一致 する結果をここに示す。また, 1 対の電極が置かれた溶液の 温度が同時に変化する等温状態では, 理論的には温度変化 による電極電位は同様に変わるのでオフセット電圧の変化 は考えられない。しかし, 実際には電極表面状態の不均一 性のために温度変化の影響が生じる。その等温温度係数 (isothermal coefficient) は, 非等温電位係数の $1 / 100$ 程度で あることを等温電位特性により示す。

\section{2. 電極電位と電気化学センサの構造}

〈2·1〉電極電位 塩化物イオン $\mathrm{Cl}^{-}$を含む電解溶液 中における銀-塩化銀電極の電極反応は次式で示される。

$$
\mathrm{AgCl}+e \rightleftarrows \mathrm{Ag}+\mathrm{Cl}^{-}
$$

上式の反応に対する平衡電極電位 $V A g-A g C l$ はネルンスト の式からつぎのように与えられる。

$$
V_{A g-A g C l}=V_{A g-A g C l}^{0}-\frac{R T}{F} \ln a_{C l^{-}}
$$

ここで, $V^{0} \mathrm{Ag}-\mathrm{AgCl}$ は銀-塩化銀電極の標準電極電位（イオン 


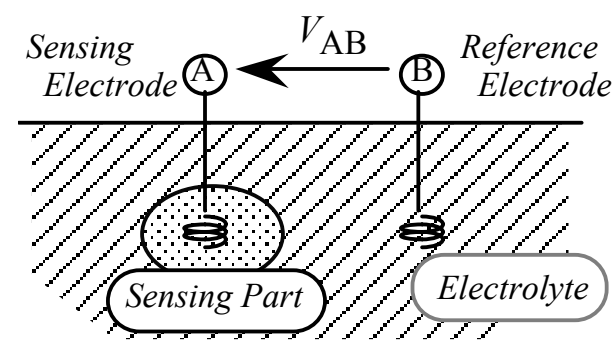

Fig. 1. A Schematic Model of Chemical Sensor

活量 $a_{C^{-}}=1$ のときの標準水素電極電位に対する電位)， $a_{C^{-}}$ は塩化物イオンの活量である。また， $R, T, F$ はそれぞれ 気体定数, 絶対温度, ファラデー定数を表す。

〈2·2〉 電気化学センサの構造 電気化学的原理を用 いたセンサの構造は Fig. 1 に示すような形からなるのが一 般的である。バイオセンサの場合は，塩化物イオン $\mathrm{Cl}^{-}$を 含む電解溶液中で使用されることがほとんどであり，銀-塩 化銀電極は電位検出用電極としては最適な電極である。

ここでは，基準電位を得るための参照電極（reference electrode）と信号変換部（sensing part）内部の電位信号検出 用電極 (sensing electrode) のそれぞれが銀-塩化銀電極から 構成されているものと仮定する。

参照電極に対する信号電極間の電圧 $V_{A B}$ は，検出信号 $V_{s}$ と銀-塩化銀電極対のオフセット電圧 $V_{\text {offset }}$ から成り, 次式 のように示される。

$$
V_{A B}=V_{S}+V_{o f f s e t}
$$

したがって信号 $V_{s}$ を高精度で得るためには, 電極オフセッ 卜電圧は検出信号に比べて十分小さいこと，あるいは使用 条件下においてオフセット電圧の変化分が無視できること が望まれる。

\section{3. 実験方法}

〈3・1〉 銀-塩化銀電極の作製方法 本実験に用いた 銀-塩化銀電極の作製には，前報 ${ }^{(4)}$ と同様に電極母材には直 径 3[mm], 純度 $99.99 \%$ の銀線を使用し, 塩化カリウム溶液ま たは塩化ナトリウム溶液 $(0.1 \sim 1.0[\mathrm{~mol} / \mathrm{kg}])$ 中での電解法に

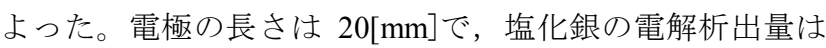
$3\left[\mathrm{C} / \mathrm{cm}^{2}\right]$ である。実験に用いた電極の構造を Fig. 2 に示す。

$\langle 3 \cdot 2\rangle$ 電解溶液および温度制御方法実験に使用し た溶液は，イオン交換水の蒸留水（WAQ123，ヤマト）を用 い，試薬特級塩化カリウム，あるいは塩化ナトリウム（和 光純薬工業）により調合した。

試験用電極セルの温度制御は以下のようである。すなわ ち, 1 対の電極システムにおいて, 溶液は通じているがそれ ぞれの電極周囲の溶液温度を異なった状態に保持するため に, 次項で説明するような二重構造のガラス容器を用いた。 この電極セルシステムを断熱材で覆い, 恒温電磁シールド 室（PID 連続温度制御， $2 \times 2 \times 2\left[\mathrm{~m}^{3}\right]$ ) 内に入れた。さらにシ ールド室が置かれた実験室は空調（on-off 制御）し，全体で

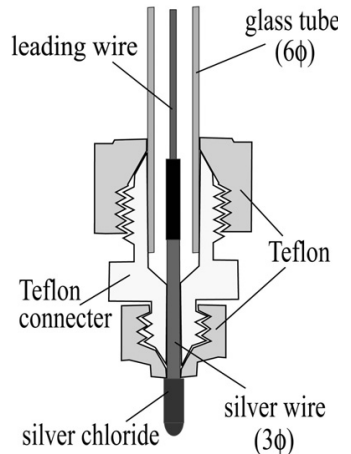

Fig. 2. Schematic Structure of $\mathrm{Ag}-\mathrm{AgCl}$ Electrode

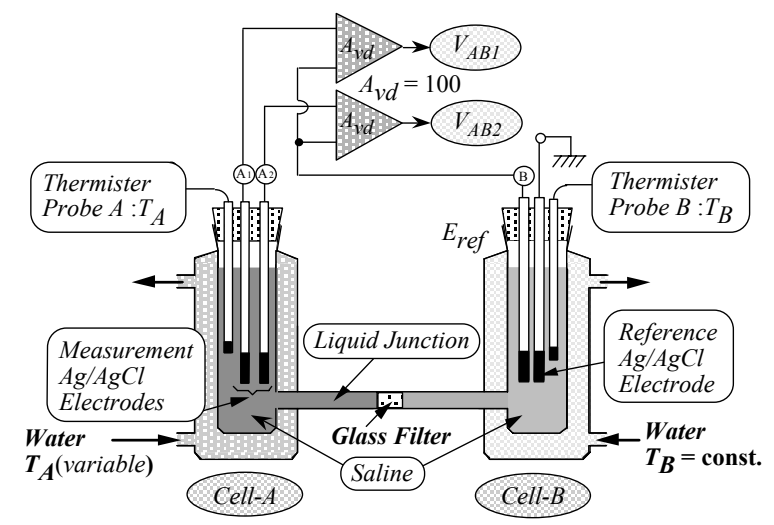

Fig. 3. Schematic Structure of $\mathrm{Ag}-\mathrm{AgCl}$ Electrode Cell for Non-isothermal System

三重の温度制御を行った。試験用電極セルの温度制御の範 囲は $15 \sim 45^{\circ} \mathrm{C}$ であり，その安定度は電位計測期間（最長時 間 100 時間）内で $\pm 0.05^{\circ} \mathrm{C}$ 以内である。また, 温度制御は, LabVIEW 7.1 (National Instruments) によった。

〈3.3〉 非等温状態における電極電位の温度特性同 じ溶液内において 1 対の電極システム, 寸なわち 1 対の電 極 A，B をそれぞれ異なる溶液温度状態にするために Fig. 3 に示すような二重セル形恒温システムを用意した。セル A, セル B のそれぞれの外側槽は自作ペルチエ熱交換素子装置 （SL-20WW，冷却能力：100W，日本ブロア）により温度制 御された循環水が試験用セル内の溶液温度を強制的に一定 值に保つようにした。2つのセルの内部溶液 (それぞれの溶 液量 : 約 200[ml]）の連結部には, 溶液間における対流を防 ぐ目的で荒目のガラスフィルタを入れた。

〈3.4〉等温状態における電極電位の温度特性同じ 溶液中にある 1 対の銀-塩化銀電極の電極電位差は, 温度が 変化しても理論的には常にゼロである。ここでは, 温度を 変えて十分時間をかけた定常状態において上述の関係がど の程度成り立つかを実験的に確認する目的で, Fig. 4 のよう なシステムを用いた。電極セル内の液量は約 $400[\mathrm{ml}]$, 熱交 換器には SL- $40 \mathrm{~W}$ （冷却能力：200W, 日本ブロア）を使用 した。

〈3.5〉電極電位と温度の計測電極電位計測には, FET 入力, 低入力電流, 高安定度オペアンプ OPA111BM 


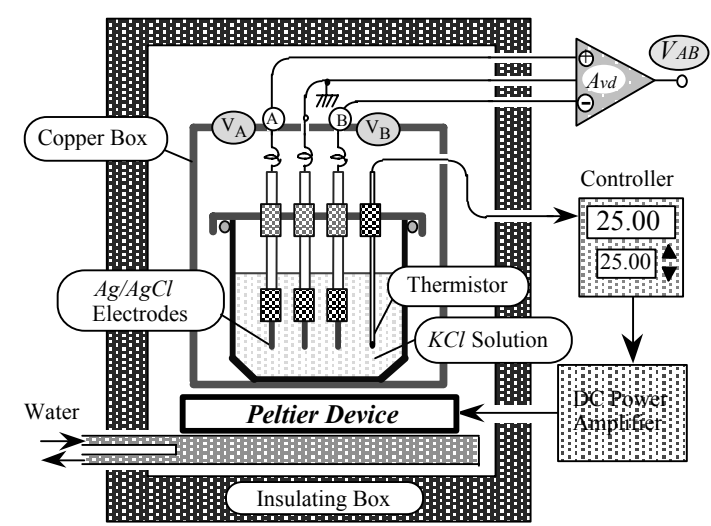

Fig. 4. Isothermal Electrode Potential Measurement System

(Burr-Brown), あるいはチョッパ・スタビライズドオペアン プ MAX421(Maxim) により構成された自作プリアンプを用 いた。また低熱起電力シールドケーブル（Keithley SC123） を使用し, 熱起電力の影響に十分注意した。周波数帯域は $\mathrm{DC} \sim 0.1[\mathrm{~Hz}]$ である。

溶液温度の計測には, 先端部の直径約 $1.5[\mathrm{~mm}]$ のビート形 サーミスタ $402 \mathrm{ET}\left(R_{25}=4 \mathrm{k} \Omega, B(\mathrm{~K})=3,100\right.$, 石塚電子), また 温度制御用としては白金測温抵抗体センサ (Model R060-11, Pt100，CHINO）を用い，それぞれ水晶温度計（DMT-600， 東京電波）により校正した.

なお，計測されたそれぞれの電極電位と温度データは， LabVIEW 7.1 により収集, 表示, 保存処理を行った。

\section{4. 実験結果}

$\langle 4 \cdot 1\rangle \quad$ 非等温電極電位一温度特性 同じ溶液温度状 態にある 1 対の銀-塩化銀電極システムにおいて，基準とす る電極 $\mathrm{B}$ の溶液温度を一定 $\left(T_{\mathrm{B}}=25.0\left[{ }^{\circ} \mathrm{C}\right]\right)$ とし, 試験用電 極 $\mathrm{A}$ の溶液温度 $T_{\mathrm{A}}$ を $15 \sim 45\left[^{\circ} \mathrm{C}\right]$ の範囲で変えたときの電極 $\mathrm{A}$ の電極 $\mathrm{B}$ に対する電極電位の関係を Fig. 3 の計測システ ムにより計測した。このような状態は非等温と呼ばれる。

Fig. 5 にその測定結果を示すが, 同図の上部には $90[\mathrm{~min}]$ 毎 に $5\left[{ }^{\circ} \mathrm{C}\right]$ の間隔で変化させた溶液温度 $T_{\mathrm{A}}$, そして同下部には 基準電極 $\mathrm{B}$ に対する試験電極 $\mathrm{A}$ の電極電位 $V_{\mathrm{AB}}$ が示されて いる。なお Fig. 3 のセル A 内には， 2 本の試験電極が示され ているが，これは電極サンプル間の計測データの再現性を 確認するために同時に複数個の試験電極を用いたことを示 すものである。

溶液の濃度は，0.1〜 $1.0[\mathrm{~mol} / \mathrm{kg}]$ の範囲で変えた。Fig. 6 に 塩化カリウム溶液における濃度別の非等温電極電位一温度 特性を示す。Fig. 6 の非等温電極電位一温度特性において, $25^{\circ} \mathrm{C}$ 近傍における勾配から求めた塩化カリウム溶液中の非 等温温度係数とイオン活量との関係を Fig. 7 に示す。この温 度係数は熱温度係数（thermal coefficient）と呼ばれることも ある。同図中に直線で示されている理論值は, 文献( 5 )より 得られる非等温に対する標準電極電位の温度係数とネルン ストの式の第 2 項から算出したものである。同図には参考 として, 塩化ナトリウム溶液における温度係数も示す。な

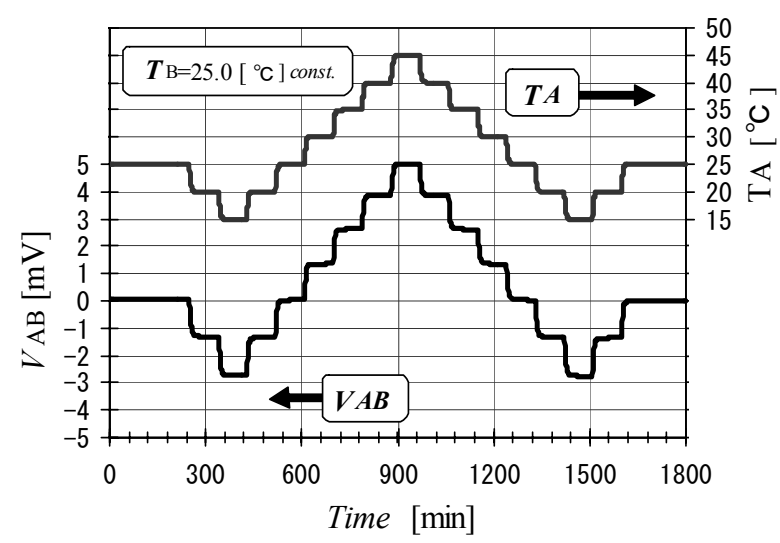

Fig. 5. Non-isothermal Electrode Potentials and One Temperature Cycle in $1 \mathrm{~mol} \mathrm{KCl}$ Solution

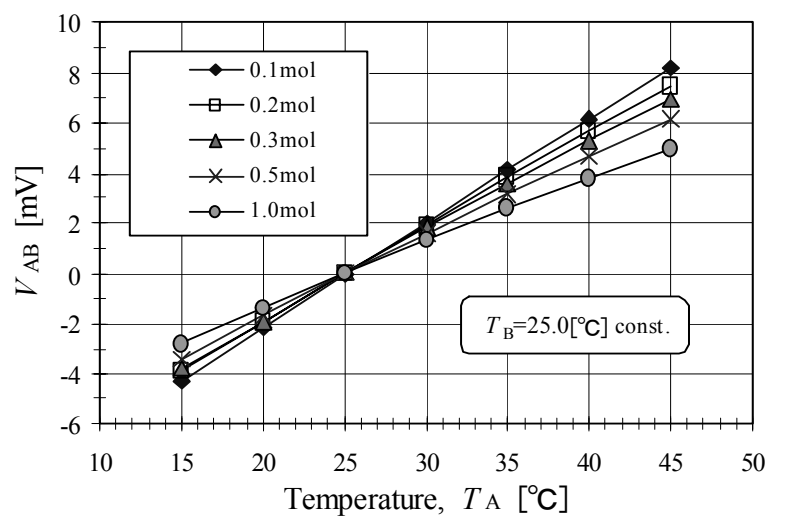

Fig. 6. Non-isothermal Electrode Potentials $V \mathrm{AB}$ vs. Temperatures in $\mathrm{KCl}$ Solutions

お, 溶液濃度からイオン活量を求めるための平均イオン活 量係数は文献( 6 )によった。

Table 1 に, 塩化カリウムと塩化ナトリウム溶液の濃度 0.1 $\sim 1.0[\mathrm{~mol} / \mathrm{kg}]$ に対応する塩化物イオンのイオン活量とそれ に対する非等温温度係数のネルンストの式より得られる理 論值と実験で得られた実測值をまとめて示す。

〈4·2〉等温電極電位一温度特性 溶液中の 1 対の銀塩化銀電極の温度が定常状態にあるとき, その電極間の電 極電位は理論的にはゼロになる。しかし実際には，電極表 面の不均一性のためにある值, すなわち電極オフセット電 圧を示すことが一般的である。このオフセット值は, 電解 処理後の数日間は一定方向に変化するドリフト現象があ り, その後ある值に落ち着く。同一溶液内において試料電 極を並列接続して電解処理をした場合, そのオフセット電 圧のバラツキ範囲を小さくすることができる。

ここでは電極電位が十分に安定になった電極を用いて, Fig. 4 の装置により溶液温度を変えたときの電極間のオフ セット電圧の様子, すなわち等温特性を調べた。溶液温度 が一定值になった時の定常電圧值をプロットした結果が Fig.8 である。なお, $25\left[{ }^{\circ} \mathrm{C}\right]$ における電極オフセット電圧は, 
溶液濃度により $20[\mu \mathrm{V}]$ 程度の差異があるが, ここでは比較 のため $0[\mathrm{~V}]$ に合わせて表示した。

\section{5. 考察}

〈5·1〉電極電位および温度計測の信頼性電極電位 の計測は, $\langle 3 \cdot 5\rangle$ 節に述べたように自作直流差動増幅器に よった。入力端子のリーク電流は数 $\mathrm{pA}$ 程度（実測值）であ り，実験に使用した銀-塩化銀電極（見かけの電極面積 : 約 $\left.2\left[\mathrm{~cm}^{2}\right]\right)$ に対してはリーク電流の影響は無視できる值であ る。また，計測周波数帯域は $\mathrm{DC} \sim 0.1[\mathrm{~Hz}]$ とした。長時間 (約 24 時間) における信頼性 (ゆらぎおよびドリフト電圧) は $\pm 0.5[\mu \mathrm{V}]$ 以内であった。また, 電極電位の計測では八ム 雑音等の外来雑音を避ける目的で, 1 対の試料電極と同種の 銀-塩化銀電極を基準とする電極セル構成にした (Fig. 3, Fig. 4 参照)。溶液温度は, ビート形サーミスタを用い水晶温度 計（確度 : $0.01\left[{ }^{\circ} \mathrm{C}\right]$ ）により校正して計測した。長時間にお ける安定度は土0.005 $\left[{ }^{\circ} \mathrm{C}\right]$ であった。以上のことから実験で得 られた電極電位および温度計測の信頼性は十分であると考 える。

なお，電位および温度計測におけるデータ処理には， LabVIEW 7.1 を利用し，データ収集は 1 [min]毎に行った。

〈5·2〉 電極電位の再現性＼cjkstart測定に用いた銀-塩化銀電 極は電解処理後に約 2 週間程度エイジングすると電極電位 の差は数 $10[\mu \mathrm{V}]$ 以内になった ${ }^{(4)}$ 。本測定では 10 本の電極を 同時に作製し，試料電極はその中から選択して使用した。

電極電位の非等温温度特性を調べるために, Fig. 5 のよう な温度サイクル (時間間隔 : $90[\mathrm{~min}]$, 温度ステップ: $5\left[{ }^{\circ} \mathrm{C}\right]$, 温度範囲 : $15 \sim 45\left[{ }^{\circ} \mathrm{C}\right]$, 開始温度 : $25\left[{ }^{\circ} \mathrm{C}\right]$, 終了温度 : $25\left[{ }^{\circ} \mathrm{C}\right]$, 総ステップ数：17，1 サイクル周期：約 26[hr]）を用いた。

電極電位計測においてはヒステリシス特性がみられるが $\pm 10 \%$ 以内に収まるまでサイクルを続けた。多くの場合は 3

Table 1. Non-isothermal Coefficient of $\mathrm{Ag}-\mathrm{AgCl}$ Electrode Potential vs. Ionic Activity of Chloride in $\mathrm{KCl}$ and $\mathrm{NaCl}$ Solutions

\begin{tabular}{|c|c|c|c|c|}
\multicolumn{2}{|c}{ (a) $K C l$ Solution } \\
\hline $\begin{array}{c}\text { Concentration } \\
{[\mathrm{mol} / \mathrm{kg}]}\end{array}$ & $\begin{array}{l}\text { Ionic } \\
\text { Activity } \\
\end{array}$ & \multicolumn{2}{|c|}{$\begin{array}{c}\text { Non-isothermal } \\
\text { coefficient }\end{array}\left[\mathrm{mV} /{ }^{\circ} \mathrm{C}\right]$} & \multirow{2}{*}{$\begin{array}{c}\text { Error } \\
{[\%]}\end{array}$} \\
\cline { 3 - 4 } & {$[\mathrm{mol} / \mathrm{kg}]$} & Theoretical & Measured & \\
\hline 0.1 & 0.077 & 0.434 & 0.421 & -3.0 \\
\hline 0.2 & 0.144 & 0.380 & 0.381 & 0.26 \\
\hline 0.3 & 0.206 & 0.349 & 0.359 & 2.87 \\
\hline 0.5 & 0.326 & 0.310 & 0.319 & 2.90 \\
\hline 1.0 & 0.604 & 0.256 & 0.258 & 0.78 \\
\hline & 1.000 & $\left.0.213^{*}\right)$ & & \\
\hline
\end{tabular}

*) cited from reference (5)

\begin{tabular}{|c|c|c|c|c|}
\hline \multirow{3}{*}{$\begin{array}{l}\text { Concentration } \\
{[\mathrm{mol} / \mathrm{kg}]}\end{array}$} & \multirow{3}{*}{$\begin{array}{l}\text { Ionic } \\
\text { Activity } \\
{[\mathrm{mol} / \mathrm{kg}]}\end{array}$} & \multirow{2}{*}{\multicolumn{2}{|c|}{$\begin{array}{c}\text { Thermal coefficient } \\
{\left[\mathrm{mV} /{ }^{\circ} \mathrm{C}\right]}\end{array}$}} & \multirow{3}{*}{$\begin{array}{r}\text { Error } \\
{[\%]}\end{array}$} \\
\hline & & & & \\
\hline & & Theoretical & Measured & \\
\hline 0.1 & 0.078 & 0.433 & 0.413 & -4.6 \\
\hline 0.2 & 0.147 & 0.378 & 0.359 & -5.1 \\
\hline 0.3 & 0.213 & 0.346 & 0.327 & -5.5 \\
\hline 0.5 & 0.341 & 0.306 & 0.280 & -8.4 \\
\hline 1.0 & 0.657 & 0.249 & 0.219 & -12.1 \\
\hline
\end{tabular}

サイクルで条件は満たされた。また, サンプル間の再現性 をみるために同一電極セル内に 2 組の電極対を設け, サン プル間の差異も監視した。ただし溶液濃度が $0.1[\mathrm{~mol} / \mathrm{kg}]$ の 場合は，温度を変えたときの電極電位が安定になるまでの 時間が，より高濃度溶液の時に比べて長い時間を要するた め, 測定の 1 ステップ当りの時間を 2〜 $5[\mathrm{hr}]$ とし十分な時間 をかけて安定化させながら測定した。

$\langle 5 \cdot 3\rangle$ 電極電位の非等温温度特性 Fig. 7 の電極電 位の理論的非等温温度係数 $k_{T}$ は, ネルンストの式から次式 のように求められる。

$$
k_{T}=\frac{\partial V_{A g-A g C l}}{\partial T}=\frac{\partial V_{A g-A g C l}^{0}}{\partial T}-\left(\frac{R}{F}\right) \ln a_{C l^{-}}
$$

上式の第 1 項は標準電極電位の温度係数であるが文献( 5 ) より得られる $0.213[\mathrm{mV} / \mathrm{deg}]$ の值を用いた。また第 2 項は塩 化物イオン活量から求められるが, 塩化カリウムおよび塩 化ナトリウム溶液のイオン活量の算出は, 文献(6)の平均イ オン活量係数によった。

塩化カリウム溶液中において実測された非等温温度係数

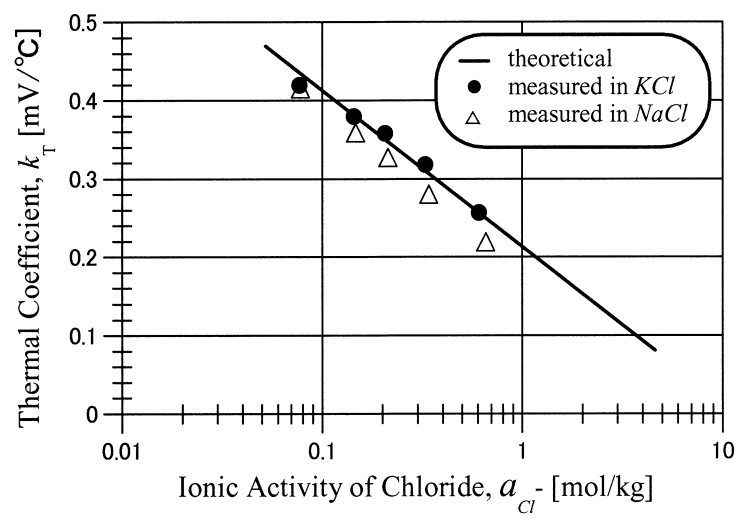

Fig. 7. Non-isothermal Temperature Coefficient of Electrode Potential vs. Ionic Activity of Chloride in $\mathrm{KCl}$ and $\mathrm{NaCl}$ Solutions

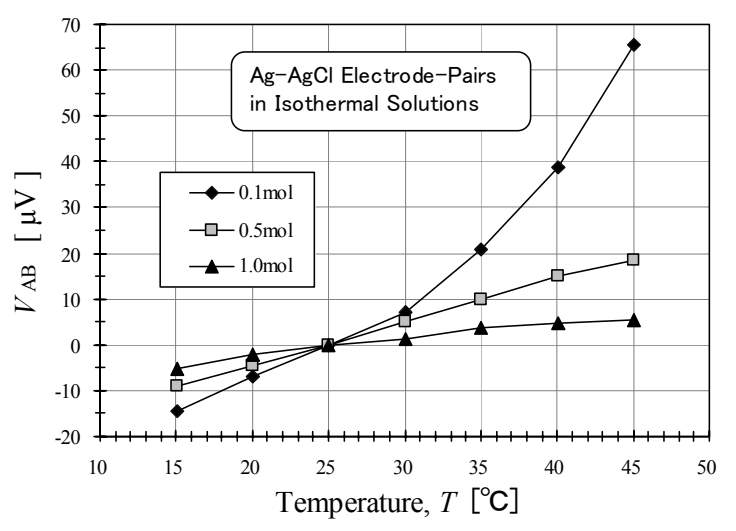

Fig. 8. Isothermal Electrode Potentials $V A B$ vs. Temperatures in $\mathrm{KCl}$ Solutions 
は, Fig. 7 または Table 1(a) に示すように理論值によく一致 した。また, 塩化ナトリウム溶液においても同表(b)のように ほぼ一致するが，理論值に比べて若干小さい值を示した。 この理論值の(4)式による計算では, 塩化物イオン活量の温 度依存性はあまり大きくないこと ${ }^{(7)}$, またその対数值である ことを考慮して塩化物イオン活量を一定值として計算し た。さらに, 溶液間の温度が異なる場合に生じる熱液間電 位 (thermal liquid junction potential ${ }^{(5)}$, アニオン, カチオンの 拡散係数の温度係数差による拡散電位）の影響などが原因 と考えられるが，詳しくは不明である。

なお試料用銀-塩化銀電極の電解処理は, 塩化カリウムあ るいは塩化ナトリウム溶液の 2 種類の溶液中で処理したが, それらの電極間に温度特性の差異はみられなかった。

$\langle 5 \cdot 4\rangle$ 電極電位の等温温度特性 1 対の同一種電極 が同じ電極セル内にあるときの電極電位の差（オフセット 電圧または不斉電位とよばれる）は理論的にはゼロである が，実際には電極表面状態の不均一性などの理由によりあ るオフセット電圧を示すことになる。塩化カリウムあるい は塩化ナトリウム溶液中の銀-塩化銀電極の場合は, 前項で 述べたようにオフセット電圧を数 $10[\mu \mathrm{V}]$ 以内にすることが 可能である。

以上は一定な温度中のことであるが，電極セル内の溶液 の温度が変化したときには, 電極表面状態の不均一性など によりオフセット電圧の值が変わる。このような温度特性 をここでは等温温度特性と呼んでいる。この特性を知るた めには実験的に求める以外に方法はないが，(4)式より塩化 物イオン活量濃度が大きいほど温度に対する電極電位の変 化率は小さくなることがわかる。等温温度係数は, それぞ れの電極電位の変化の差であるからその差も小さくなると 考えられる。Fig. 8 の実験結果にもその傾向がみられ, 等温 温度係数は非等温温度係数に対して 2 桁程度小さい。

\section{6. むすび}

生体電子計測, とくにバイオセンサにおいて参照電極あ るいは電位計測用電極として銀-塩化銀電極が用いられると き, その電極電位の変動は計測の精度を左右する重要な要 因の一つである。本研究では, このような観点から温度変 化と電極電位の関係について実験的な検討を行った。その 結果, 1 対の電極間に温度差があるときの温度係数（非等温 温度係数) は $0.42\left[\mathrm{mV} /{ }^{\circ} \mathrm{C}\right](0.1[\mathrm{~mol} / \mathrm{kg}]$ 中 $) \sim 0.26\left[\mathrm{mV} /{ }^{\circ} \mathrm{C}\right]$ $(1.0[\mathrm{~mol} / \mathrm{kg}]$ 中 $]$ であること,また等温状態ではこれらの $1 / 100$ 程度になることを明らかにした。この結果から, 塩
化物イオン濃度は高いほど電極電位への温度変化の影響は 少ないことがわかる。しかし, 溶液の塩化物イオン濃度が $3[\mathrm{~mol} / \mathrm{kg}]$ あるいは飽和溶液では塩化銀が錯塩を形成して溶 液中に溶解する ${ }^{(2)(8)}$ という難問がありその解決策は今後の 課題である。

(平成 18 年 10 月 24 日受付)

\section{文献}

(1) G. J. Janz : "Siver-Silver-Halide Electrodes", in "Reference Electrodes - Theory and Practice-", pp.179-230, (ed)D.J.G.Ives and G.J.Janz, Academic Press, New York (1961)

(2) H. Galster : "pH Measurement - Fundamentals, Methods, Applications, Instrumentation “, pp.67-195, VCH, New York (1991)

(3) L. A. Geddes and L. E. Baker : "Principles of Applied Biomedical Instrumentation", 3rd ed., pp.315-452, Wiley Interscience (1989)

(4) 田頭 功 :「生体電子計測系インタフェースとしての銀-塩化銀電極 の基本特性」, 電学論 C, 122, 9, pp.1426-1432 (2002)

(5) A. J. deBethune, T. S. Licht, and N. Swendeman : "The Temperatue Coefficients of Electrode Potentials", J. of the Electrochemical Society, 106, 7, pp.616-625 (1959)

（6）電気化学会編：(第 5 版）電気化学便覧, p.99 丸善（2000)

(7) 同上, p.100, 丸善 (2000)

(8) H. Suzuki, T. Hirakawa, S. Sasaki, and I. Karube : "An integrated three-electrode system with a micromachined liquid-junction $\mathrm{Ag} / \mathrm{AgCl}$ reference electrode", Analytica Chemica Acta, Vol.387, pp.103-112 (1999)

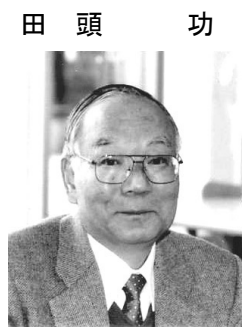

（正員） 1938 年 9 月 21 日生。1963 年 6 月東 北大学工学部通信工学科卒業。同年東北大学 工学部電子工学科助手。1 1970 年 4 月東北工業 大学電子工学科講師, 1971 年 4 月同助教授, 1981 年 4 月同教授。 2001 年 4 月同大学環境情 報工学科教授。工学博士 (東北大学)。主とし て，生体計測および信号処理に関する研究， とくに生体計測用電極の研究に従事。1993 年, 1994 年日本エム・イー学会東北支部長。電子情報通信学会, 日本医 工学会, IEEE(EMBS) 各会員。

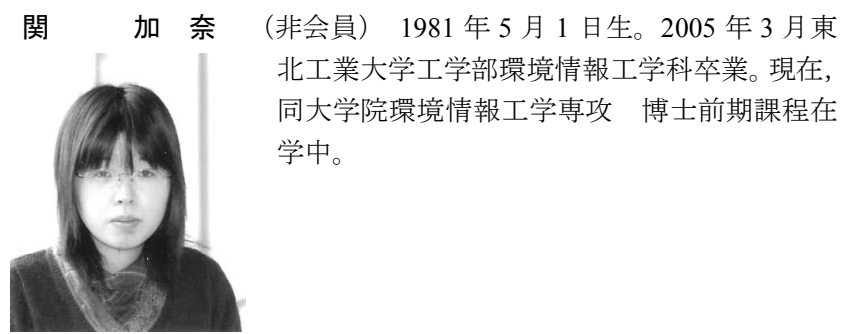

